\title{
Development of a combined method to assess the complex effect of atrazine on sex steroid synthesis in H295R cells
}

\author{
Judit Háhn a , Sándor Szoboszlay b, *, Csilla Krifaton ${ }^{\text {b }}$, Krisztina J. Kovács c , \\ Szilamér Ferenczi ${ }^{\mathrm{c}}$, Balázs Kriszt ${ }^{\mathrm{b}}$ \\ a Szent István University, Regional University Center of Excellence, 1 Páter Károly Street, Gödöllö 2100, Hungary \\ b Szent István University, Department of Environmental Safety and Ecotoxicology, 1 Páter Károly Street, Gödöllö 2100, Hungary \\ ${ }^{\mathrm{c}}$ Laboratory of Molecular Neuroendocrinology, Institute of Experimental Medicine, 43 Szigony Street, Budapest 1083, Hungary
}

\section{H I G H L I G H T S}

- New, combined method with H295R cells and bioluminescence bioreporter assay.

- Inductive effect on both estrogen and androgen synthesis by atrazine in H295R cell.

- Rapid and simple detection of the complex, indirect effect of chemicals.

\section{A R T I C L E I N F O}

\section{Article history:}

Received 11 December 2015

Received in revised form 4 March 2016

Accepted 25 March 2016

Available online 14 April 2016

Handling Editor: Frederic Leusch

\section{Keywords:}

Atrazine

H295R

Endocrine disruptor

Steroidogenesis

Estrogenic and androgenic effects

\section{G R A P H I C A L A B S T R A C T}

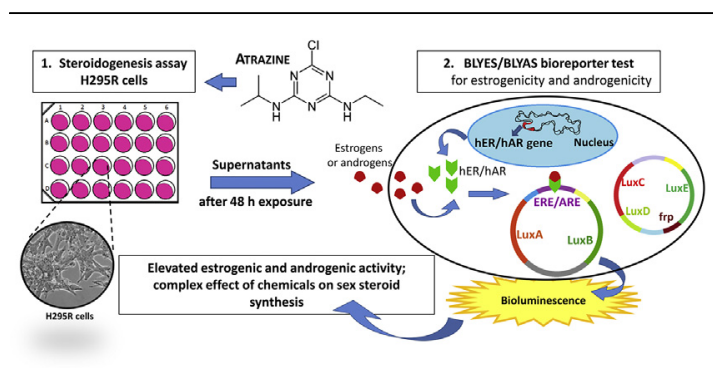

\begin{abstract}
A B S T R A C T
The aim of the study was to develop a rapid, cost-effective combined testing method to assess the indirect effect of compounds interfering with sex steroid synthesis and to determine complex effects of atrazine on estrogen and androgen synthesis in vitro on H295R human cell line. Steroidogenic assay was performed on H295R human adrenocortical carcinoma cell line. Instead of standard analytical methods, bioluminescence bioreporter assays (Saccharomyces cerevisiae BLYES and BLYAS) were used to measure estrogenic and androgenic effects of sex steroid hormones released by human cells in response to atrazine. Atrazine resulted in elevated estrogen production presumably due to its well documented inductive effect on aromatase on H295R cell line, detected by BLYES. Interestingly, results of BLYAS test showed concentration-dependent increase of androgen production in H295R cells. That indicates that atrazine can not only increase estrogen level via aromatase induction, but may interfere in androgen synthesis as well. The combined method allows us to assess the androgenic and estrogenic effect of sex steroids produced by human cells in increased or decreased quantity as a result of the different chemicals, without determining specific analytical measurement endpoints, by using the yeast based bioluminescent bioreporter test.
\end{abstract}

๑) 2016 Elsevier Ltd. All rights reserved.

\footnotetext{
* Corresponding author.

E-mail address: Szoboszlay.Sandor@mkk.szie.hu (S. Szoboszlay).
}

\section{Introduction}

Endocrine disrupting chemicals (EDCs) interfere with hormone signalling in a variety of ways depending on the chemical and the hormonal system. Many of these chemicals interact with sex 
hormone receptors (androgenic-antiandrogenic-, estrogenic-antiestrogenic effects); others affect key enzymes involved in steroid synthesis and breakdown.

Atrazine (2-chloro-4-ethylamino-6-isopropylamino-1,3,5triazine) is a member of chlorinated $s$-triazine group of herbicides having been widely used worldwide over the last 50 years. European Union has banned atrazine since 2004, but it is one of the most extensively used herbicide in North America (and several other countries) for pre- and post emergence control of broadleaf and grassy weeds in corn, sorghum, sugarcane and other crops (Sass\&Colangelo, 2006; Ghosh\&Philip, 2006).

Although atrazine does not bind to androgen and estrogen receptors (Kojima et al., 2003; Roberge et al., 2004; Suzawa\&Ingraham, 2008), it has been associated with various endocrine disrupting effects including reduction of number and motility of sperm (Kniewald et al., 2000), hermaphroditism and demasculinization in frogs (Hayes et al., 2002, 2006, 2010, 2011), change in sex- and estrogen-androgen ratio in fish and amphibian (Oka et al., 2008; Suzawa\&Ingraham, 2008). Furthermore, atrazine has been reported to up-regulate aromatase activity in vitro in H295R human adrenocortical carcinoma cells (Sanderson et al., 2000, 2002). Aromatase enzyme is responsible for the conversion of androgens to estrogens; therefore, atrazine causes elevated estrogen production due to its inductive effect on aromatase. Moreover, atrazine induces tumours of the mammary gland and reproductive organs (Pintér et al., 1990). According to the World Health Organization International Agency for Research on Cancer (IARC) there is sufficient evidence in experimental animals for the carcinogenicity of atrazine, however, in humans, atrazine is not classifiable (Group 3) since 1999 (IARC, 1999).

In 1996, EPA formed the Endocrine Disruptor Screening and Testing Advisory Committee (EDSTAC), charging the Committee to develop a screening program that would provide necessary information to make regulatory decision about the endocrine effects of approximately 87000 existing and new chemicals that require screening for endocrine disrupting activity. EDSTAC created a tiered Conceptual Framework consisting three major activities: i. Priority setting to obtain and evaluate existing data and to identify chemical substances and mixtures requiring further testing; ii. Tier 1 Screening to detect chemicals and mixtures capable of interacting with estrogen, androgen, or thyroid (EAT) hormone system; iii. Tier 2 Screening to precisely determine and identify the mode of action of the endocrine disrupting ability of chemicals and mixtures selected by Priority setting and/or Tier 1 (EDSTAC, 1998).

There are various techniques and methods available to analyze endocrine disrupting effects of EDCs. However, many of these tests focus on certain endpoints, e.g., estradiol and testosterone concentration measured by ELISA, or specific receptor-binding and gene-expression assays, while the complexity of multiple biological effects of EDCs on endocrine system is poorly investigated.

Herein we report a novel test method and a concentrationresponse study for determine the complex effects of atrazine on sex steroid synthesis in H295R human adrenocortical carcinoma cells.

The human H295R adrenocortical carcinoma cell line expresses most of the key enzymes required for steroidogenesis (Gazdar et al., 1990; Rainey et al., 1993, 1994). Therefore, the cell line is a useful in vitro model to investigate steroidogenic pathways and processes (Hecker \& Giesy, 2008; USEPA, 2011).

Sanseverino et al. (2005) and Eldridge et al. (2007) developed a low cost and rapid bioassay, measuring estrogenic-, androgenic potential and toxicity with the purpose to create an assay that is applicable for Tier 1 high-throughput screening in EDSTAC and for monitoring endocrine-disrupting activity of unknown chemicals. Saccharomyces cerevisiae strains (BLYES and BLYAS) were constructed by inserting human estrogen and androgen receptor genes in the chromosome, a series of estrogen and androgen response elements, and the prokaryotic lux-genes of Photorhabdus luminescence. When an estrogenic or androgenic compound enters the cell of Saccharomyces cerevisiae BLYES and BLYAS, it is bound by the human estrogen and androgen receptor, a complex is formed, activating the lux-genes, and resulting in bioluminescence. The constitutive control strain (S. cerevisiae BLYR) is used to assess the toxicity of samples with a decrease in bioluminescence.

These bioluminescence bioreporters are appropriate tools to measure effects of estrogens and androgens. Here, we have combined in vitro steroidogenesis assay with bioreporters to reveal indirect and complex effects of atrazine on sex steroid synthesis.

\section{Materials and methods}

\subsection{H295R cell line and culture conditions}

H295R human adrenocortical cell line was obtained from the CLS Cell Line Service GmbH (Germany, NCI-H295R, no. 300483). Cells were cultured as described in OCSPP Guideline 890.1550. Briefly, upon arrival, cells were propagated in a complete growth medium consisting of 1:1 mixture of DMEM:F12 medium supplemented with ITS + Premix (insulin, transferrin, selenium, bovine serum albumin, and linoleic acid; final dilution 1:100; BD) and fetal calf serum FCS (final concentration $2.5 \% \mathrm{v} / \mathrm{v}$ ) for at least five passages. Aliquots were regularly frozen in liquid $\mathrm{N}_{2}$. Cells were harvested between passages 5 and 10 by $0.5 \%$ trypsin and $2 \times 10^{5}$ cells were plated into 24 wells' plates resulting in $60-70 \%$ confluency by $24 \mathrm{~h}$. H295R cells were exposed to test compounds or medium and solvent ( $1 \mu \mathrm{l} \mathrm{DMSO} / \mathrm{ml}$ medium) controls for $48 \mathrm{~h}$. For steroidogenesis assay, cells were treated with the known aromatase inducer forskolin (CAS 66575-29-9, purity >99\%), inhibitor prochloraz (CAS 67747-09-5, purity 98.6\%) and atrazine. Forskolin is also an adenylyl-cyclase activator chemical and results in an elevated cAMP level. That is a second messenger and plays an essential role in the adrenal steroidogenesis by activating the protein kinase A (PKA) signalling pathway (Seamon et al., 1981; Hecker et al., 2006) and resulting in increased estrogen and androgen level at the same time. Prochloraz acts as an androgen and estrogen receptor antagonist and inhibit steroidogenic enzymes such as CYP17A1 (Vinggaard et al., 2006) and CYP19A1 (aromatase) (Andersen et al., 2002) decreasing the level of testosterone and estrogens. Chemicals were purchased from Sigma-Aldrich Ltd. Cells in 24-well culture plates containing $1 \mathrm{ml}$ medium per well, were exposed to various concentrations of atrazine $(1,3,10,30,100$ and $300 \mu \mathrm{M})$, forskolin $(0.03,0.1,0.3,1,3$ and $10 \mu \mathrm{M})$ and prochloraz $(0.01,0.03,0.1,0.3,1$ and $3 \mu \mathrm{M}$ ) dissolved in $1 \mu \mathrm{l}$ of dimethyl-sulfoxide (DMSO; CAS67$68-5$, purity $\geq 99.7 \%$, Sigma-Aldrich). In parallel with atrazine, treatments with at least two different concentrations of positive control chemicals (forskolin and prochloraz) were run as quality controls at the same time, according to the recommendations of the OCSPP Guideline. At the end of the experiment, culture supernatants were collected and frozen at $-20^{\circ} \mathrm{C}$. Cells were rinsed 3 times with PBS and the plate was frozen after adding $200 \mu$ lof TRISol into each well. All treatments were carried out in duplicate in three independent experiments.

\subsection{BLYES, BLYAS and BLYR test}

S. cerevisiae strains BLYES, BLYAS and BLYR (The University of Tennesse, Knoxville) harbouring plasmids with leucine and uracil selective markers were stored at $-80^{\circ} \mathrm{C}$ and were grown overnight at $30{ }^{\circ} \mathrm{C}$ and $200 \mathrm{rpm}$ to an $\mathrm{OD}_{600}$ of 1.0 in a modified minimal medium (YMM) without leucine and uracil (Routledge \& Sumpter, 
1996).

Bioluminescence (detected in photon counts per second, CPS) was measured after $5 \mathrm{~h}$ by a VictorX Multilabel Plate Reader (Perkin-Elmer Inc., USA). BLYES, BLYAS and BLYR tests have been carried out in triplicates for each supernatant sample originated from the steroidogenesis assay and pure compounds (atrazine, prochloraz, forskolin) and have been repeated three times using S. saccharomyces cells from different stocks each time. $17 \beta$-estradiol (E2) and $5 \alpha$-dihydrotestosterone (DHT) (concentration range from $2 \mathrm{E}-05$ to $3.5 \mathrm{E}-02 \mu \mathrm{M}$ ) dissolved in $20 \mu \mathrm{l}$ methanol have been used as positive controls in each assay. Negative controls included wells with YMM + yeast cells and YMM + yeast cells + methanol.

\subsubsection{Cross-reaction between BLYAS and BLYES tests}

In order to assess the extent of possible cross-reaction, we evaluated the E2 and DHT responses detected in BLYAS and BLYES tests, respectively. $20 \mu \mathrm{l}$ of $\mathrm{E} 2$ (concentration range tested from $1.8 \mathrm{E}+02 \mu \mathrm{M}$ to $3.7 \mathrm{E}+05 \mu \mathrm{M}$ ) and DHT (from $5.4 \mathrm{E}+01 \mu \mathrm{M}$ to $1.1 \mathrm{E}+05 \mu \mathrm{M})$ dissolved in methanol were placed into wells of black, sterile, flat bottom, 96-well microplate (Grenier Bio-one Gmbh, Germany), then after evaporation of the solvent $200 \mu \mathrm{l}$ BLYES and BLYAS was added to the DHT and E2 containing wells, respectively.

\subsubsection{Estrogenicity and androgenicity of the pure test compounds}

To determine the estrogenic, androgenic and cytotoxic effects of the pure test compounds, BLYES, BLYAS and BLYR tests have been carried out with atrazine $(1,3,10,30,100$ and $300 \mu \mathrm{M})$, forskolin $(0.03,0.1,0.3,1,3$ and $10 \mu \mathrm{M})$ and prochloraz $(0.01,0.03,0.1,0.3,1$ and $3 \mu \mathrm{M}$ ) dissolved in $20 \mu \mathrm{l}$ DMSO. Wells with YMM + yeast cells and YMM + yeast cells + DMSO were applied as negative controls.

\subsubsection{Measuring estrogenicity and androgenicity of the steroid hormones produced by H295R cells}

Supernatants of H295R human cells after $48 \mathrm{~h}$ exposure to various concentrations of atrazine, forskolin and prochloraz have been examined for their estrogenic and androgenic hormone activity. Supernatants of H295R cells treated with aromatase inducer forskolin and inhibitor prochloraz have been used as positive controls which chemicals also have inductive and inhibitory effects on testosterone production. Negative controls for the basal hormone production of H295R (Medium + H295R) and solvent controls $(\mathrm{SC}=$ Medium $+\mathrm{H} 295 \mathrm{R}+$ DMSO $)$ were also included. $20 \mu \mathrm{l}$ samples were placed appropriate wells. Subsequently $200 \mu \mathrm{l}$ of cultures (BLYES, BLYAS and BLYR) were placed into each well, respectively. Bioluminescence values of supernatants of H295R treated with atrazine, forskolin and prochloraz have been compared to the solvent control (SC).

\subsubsection{Data analyses}

Statistical analyses of bioluminescence data have been performed using GraphPad Prism 5 software (GraphPad Software Inc., San Diego, USA). All data are expressed as means and standard deviations. Differences among all treatments have been determined using analysis of variance (ANOVA) followed by the Tukey's post hoc test, differences with $\mathrm{p} \leq 0.05$ were considered significant. For curve fitting and $\mathrm{EC}_{50}$ calculations, normalized bioluminescence values (CPS) versus the log of chemical concentrations $(\mu \mathrm{M})$ were plotted using the four-parametric logistic equation (Hillequation or variable slope sigmoidal equation) as a non-linear regression model to generate concentration-response curves.

Bioluminescence intensification has been determined as calculated in Krifaton et al. (2013). Briefly:

Bioluminescence intensification $(\%)=-1 \times[(\mathrm{SC}-\mathrm{S}) / \mathrm{SC}] \times 100$ where SC is the arithmetic mean of the bioluminescence values of parallel solvent controls after the incubation time and $\mathrm{S}$ represents the bioluminescence average value of parallel samples, determined at the time of contact.

\section{Results}

To examine endocrine disrupting effects of atrazine on steroid synthesis in H295R cells, a combined method with BLYES, BLYAS and BLYR bioreporters was developed. The literary $\mathrm{EC}_{50}$ values are $6.3 \pm 2.4 \mathrm{E}-04 \mu \mathrm{M}$ for $\mathrm{E} 2$ and $1.1 \pm 0.5 \mathrm{E}-02 \mu \mathrm{M}$ for DHT as positive control chemicals, using BLYES and BLYAS test, respectively (Sanseverino et al., 2009). The $\mathrm{EC}_{50}$ values (means with standard deviations from the independent bioreporter assays) were $6.46 \pm 3.7 \mathrm{E}-04 \mu \mathrm{M}$ for $\mathrm{E} 2$ and $3.91 \pm 2.0 \mathrm{E}-03 \mu \mathrm{M}$ for DHT measured in our study, thus the sensitivity of the bioreporter tests was sufficient.

\subsection{Cross-reactivity between BLYES and BLYAS tests}

Cross-reactivity was detected between the BLYES and BLYAS tests; the androgenic activity of E2 measured in the BLYAS test is nearly 30 times weaker than the effect of DHT; the total estrogenic activity of DHT when assessed in the BLYES test is almost 600 times weaker than the effect of E2. The estrogenic and androgenic effects of the estrogens and androgens produced by human cells in response to atrazine were approximately 60000 times and 7000 times weaker, respectively than that of E2 and DHT (Table 1). The atrazine concentrations in the steroidogenesis assay, due to which the supernatant of human cells causes $50 \%$ of the maximum estrogenic and androgenic effects in the bioreporter tests $\left(\mathrm{EC}_{50}\right)$, are largely the same (Fig. 3). Therefore, it can be concluded that the increased estrogenic and androgenic effects in supernatants after exposure to atrazine, detected in the BLYES and BLYAS tests, are indeed due to the increased level of both the androgen and estrogen hormones and not to the cross-reaction of estrogens with the androgen receptor and the androgens with the estrogen receptor.

\subsection{Estrogenicity and androgenicity of the pure test compounds}

In order to evaluate whether by attaching to the human estrogen and androgen receptors, forskolin, prochloraz and atrazine, directly are able to cause increase in bioluminescence, the test chemicals were examined in BLYES, BLYAS and cytotoxicity assessing BLYR tests (the concentration range was identical to the one used in the steroidogenesis assay). The bioluminescence values evoked by the different compounds and expressed in \% compared to the solvent control value are shown in Fig. 1. None of the chemicals resulted in an increase in bioluminescence as measured in the BLYES and BLYAS tests. They were not cytotoxic in the BLYR test in the highest concentration applied: forskolin, prochloraz and atrazine resulted in $4.3-12.1 \%, 6-12.6 \%$ and maximum $14.7 \%$ decrease in bioluminescence, respectively, and these values were not found significantly different from the solvent control. However, a significant decrease in bioluminescence was detected in case of pure prochloraz in BLYES and atrazine and forskolin in BLYAS tests, respectively (Fig. 1). Forskolin does not have cytotoxic effect, up to the best of the authors' knowledge. Although the decrease in the bioluminescence caused by forskolin is statistically significant, it is small-scale, especially as BLYES and BLYAS have only a modest bioluminescence (hence their role is to respond with elevated luminescence in presence of chemicals that are able to bind to the estrogen and androgen receptors), whereas the basic bioluminescence of BLYR strain is two orders of magnitude larger. Prochloraz is also an imidazole-type fungicide inhibiting the ergosterol 
Table 1

Cross-reactivity between BLYES and BLYAS tests and relative estrogenic and androgenic activity of the compounds compared to the corresponding assay standard.

\begin{tabular}{|c|c|c|c|c|}
\hline \multirow[t]{2}{*}{ Compound } & \multicolumn{2}{|l|}{ BLYES test } & \multicolumn{2}{|l|}{ BLYAS test } \\
\hline & Estrogenic activity $^{\mathrm{a}}$ & $\mathrm{EC}_{50}(\mu \mathrm{M})$ & Androgenic activity $^{\mathrm{a}}$ & $\mathrm{EC}_{50}(\mu \mathrm{M})$ \\
\hline E2 & 1 & $2,740 \mathrm{E}-04$ & $1 / 27$ & $1,290 \mathrm{E}-01$ \\
\hline DHT & $1 / 571$ & $1,570 \mathrm{E}-01$ & 1 & $4,730 \mathrm{E}-03$ \\
\hline H295R supernatant after atrazine exposure & $1 / 61350$ & $1,678 \mathrm{E}+01$ & $1 / 7256$ & $3,438 \mathrm{E}+01$ \\
\hline
\end{tabular}

a Ratio of the $\mathrm{EC}_{50}$ of the corresponding assay standard divided by the $\mathrm{EC}_{50}$ of a compound.
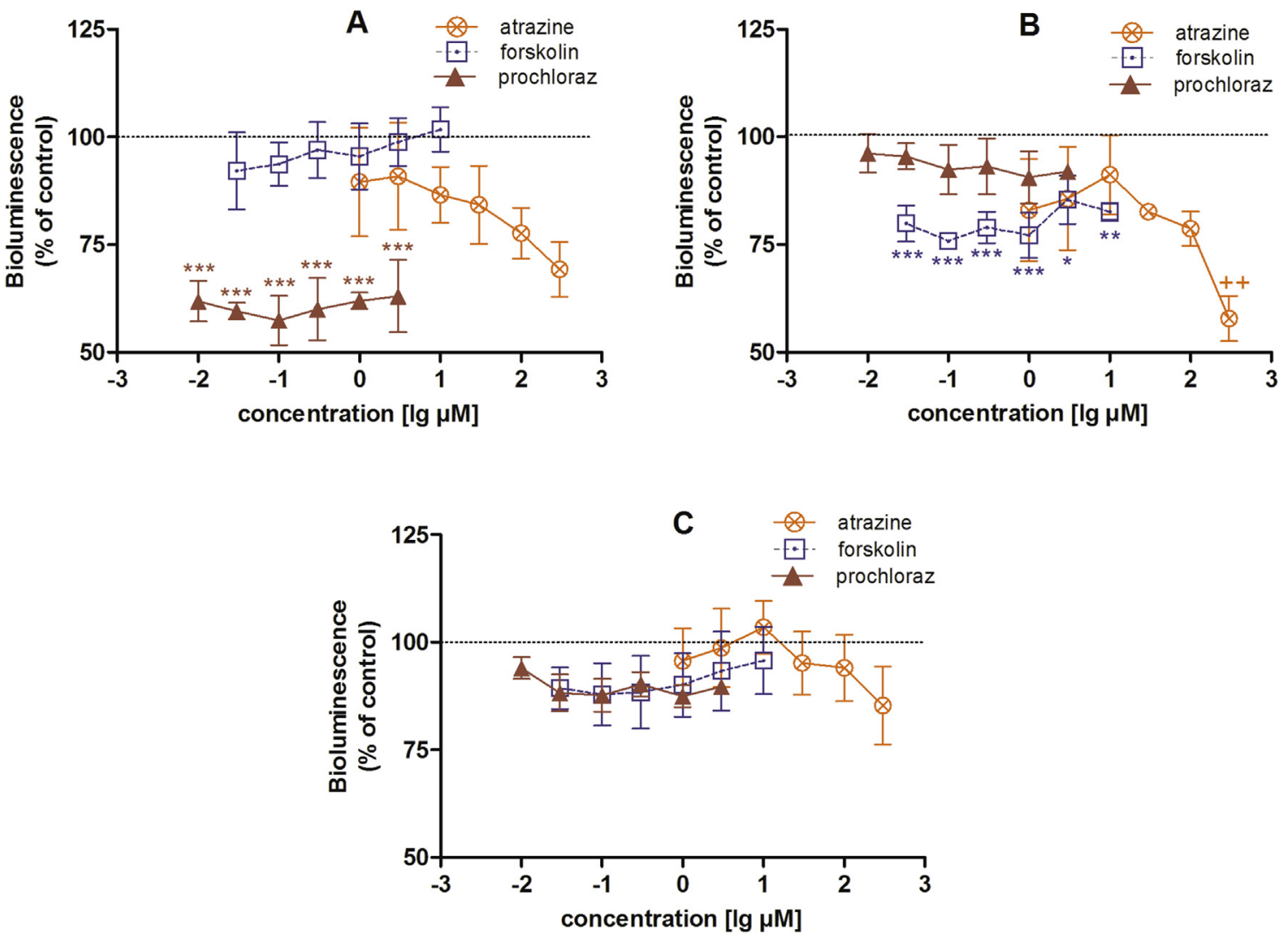

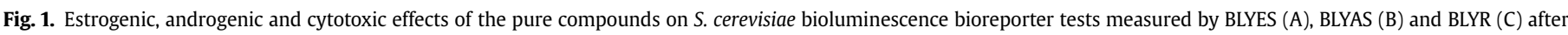

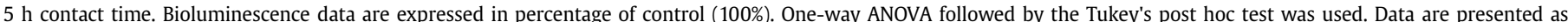

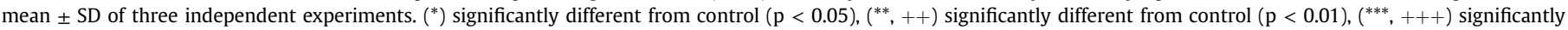
different from control $(\mathrm{p}<0.001)$. Test compounds were tested three times with BLYES/BLYAS/BLYR tests in triplicate.

biosynthesis in fungi (Paranjape et al., 2014), thus this chemical can cause a decrease in bioluminescence in the bioreporters due to its anti-fungal activity. According to Sanseverino et al. (2009), atrazine has a cytotoxic effect on the bioreporters in relatively high dose $\left(\mathrm{IC}_{20}: 5.3 \mathrm{E}+02 \mu \mathrm{M}\right.$ in BLYR) corresponding with our results (highest decrease in bioluminescence was measured at $3 \mathrm{E}+02 \mu \mathrm{M}$ of atrazine).

Our conclusion, based on these results, is that test chemicals alone cannot cause an increase in bioluminescence in the bioreporter test. Furthermore they cannot attach either to the estrogen or the androgen receptors directly. Therefore, when examining the supernatants of human cells originating from the steroidogenesis assay, we excluded that the pure test chemicals cause an increase in bioluminescence in the bioreporter tests.

\subsection{Hormone effect of supernatants of H295R cells after exposure to test compounds}

After testing pure test compounds, the supernatants originated from the steroidogenesis assay have been examined.

Supernatant samples of H295R cells treated with positive controls (forskolin and prochloraz) or atrazine did not show cytotoxic effect in BLYR test.

The effects of positive control inducer forskolin and inhibitor prochloraz, elevating and reducing estradiol and testosterone production in cells at the same time, have been measured in BLYES/ BLYAS assays. In both cases, the relative responses of estrogen and androgen hormones produced by H295R cells after exposing them to forskolin and prochloraz have met expectations. BLYES and BLYAS assays produced increased bioluminescence after exposing them to supernatants of forskolin treated H295R cells, while bioreporters showed decreased values after exposing them to supernatants of prochloraz treated H295R cells. These results indicate that BLYES and BLYAS are able to detect inductive and inhibitory effects of forskolin and prochloraz in a concentration-dependent manner (Fig. 2).

Lowest observed effect concentrations, 0.3 and $0.1 \mu \mathrm{M}$ of forskolin and 0.3 and $0.03 \mu \mathrm{M}$ of prochloraz, significantly elevated and 
abated estrogenic and androgenic effects in the supernatants of H295R cells, respectively. At a concentration $10 \mu \mathrm{M}$ of forskolin, increases in levels of estrogen and androgen hormones resulted in $38 \%$ bioluminescence intensification of BLYES and $67 \%$ bioluminescence intensification of BLYAS strains compared to the solvent (DMSO) control (SC). $3 \mu \mathrm{M}$ of prochloraz completely blocked the basal aromatase activity (i.e. estrogen production), thus BLYES detected 92\% decrease in bioluminescence compared to SC, while decreased androgenicity resulted in $76 \%$ less bioluminescence (Fig. 2). The $\mathrm{EC}_{50}$ values measured by the BLYES and BLYAS tests were $0.609 \mu \mathrm{M}$ and $0.83 \mu \mathrm{M}$ for forskolin and $0.14 \mu \mathrm{M}$ and $0.0358 \mu \mathrm{M}$ for prochloraz, respectively (Table 2). These values fall within the expected hormone effective ranges of the positive control chemicals recommended by the OPSCC Guideline. These data, meeting the Guideline's requirements regarding the sensitivity of the hormone measurement system, help the validation and are confirming the efficiency of yeast based bioreporter tests in the combined method.

Atrazine induced both estrogen and androgen production in H295R cells concentration-dependently after 48 h exposure and the elevated estrogenic and androgenic effects were detected by strains of $S$. cerevisiae BLYAS and BLYES after 5-h contact time. Lowest observed effect concentrations of atrazine were 1 and $3 \mu \mathrm{M}$ resulting in significant increase in estrogenic and androgenic effects in the supernatants measured by BLYES and BLYAS, respectively (Fig. 3).
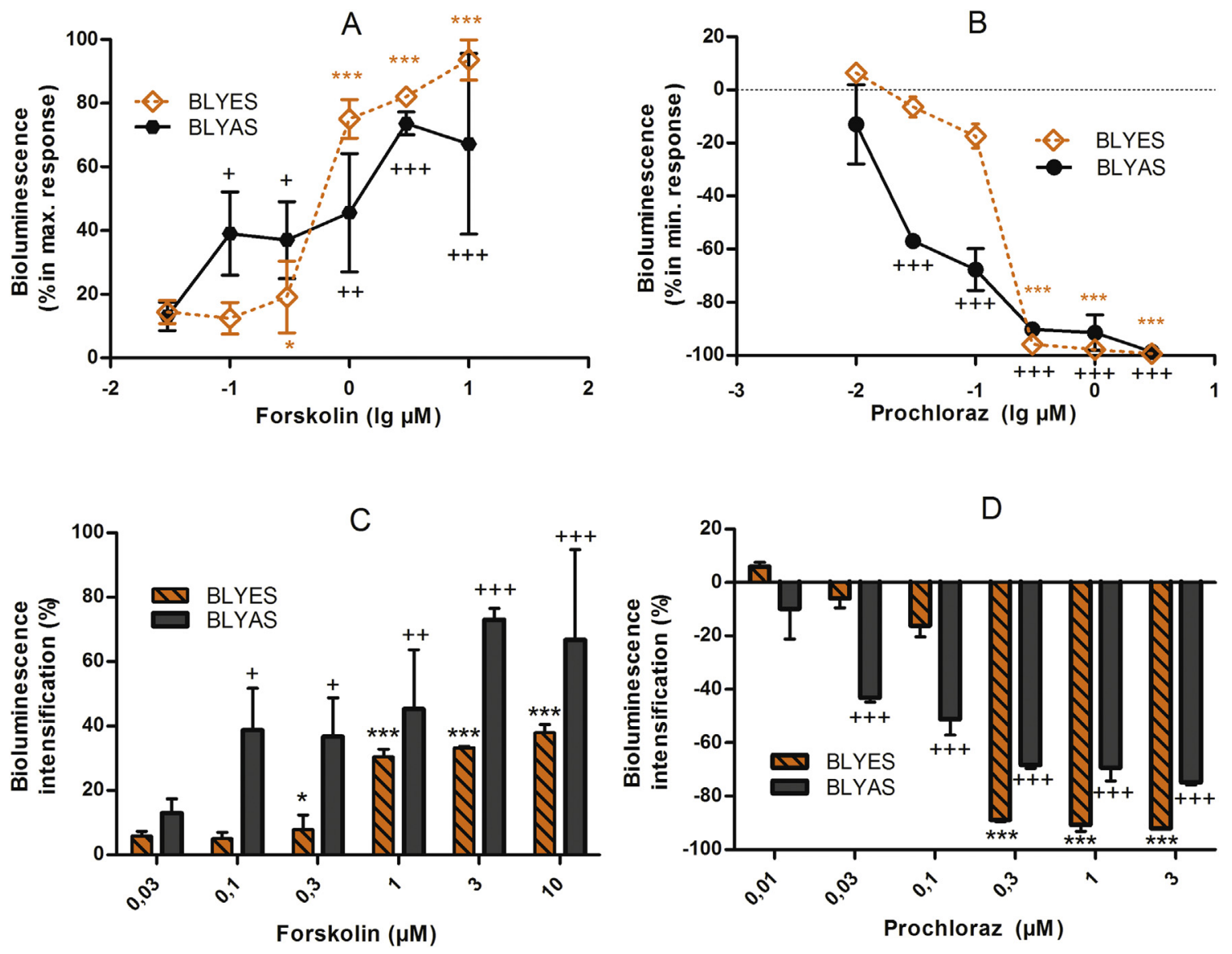

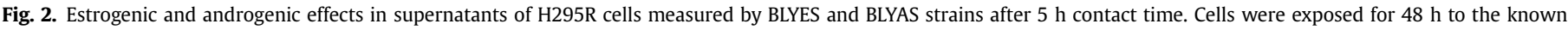

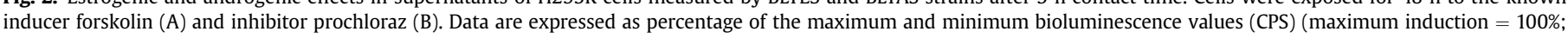

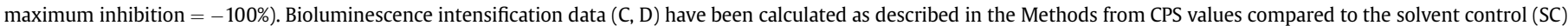

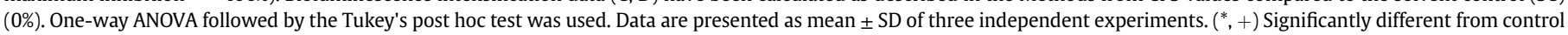
$(\mathrm{p}<0.05),(++)$ significantly different from control $(\mathrm{p}<0.01),(* * *,+++)$ significantly different from control $(\mathrm{p}<0.001)$. 

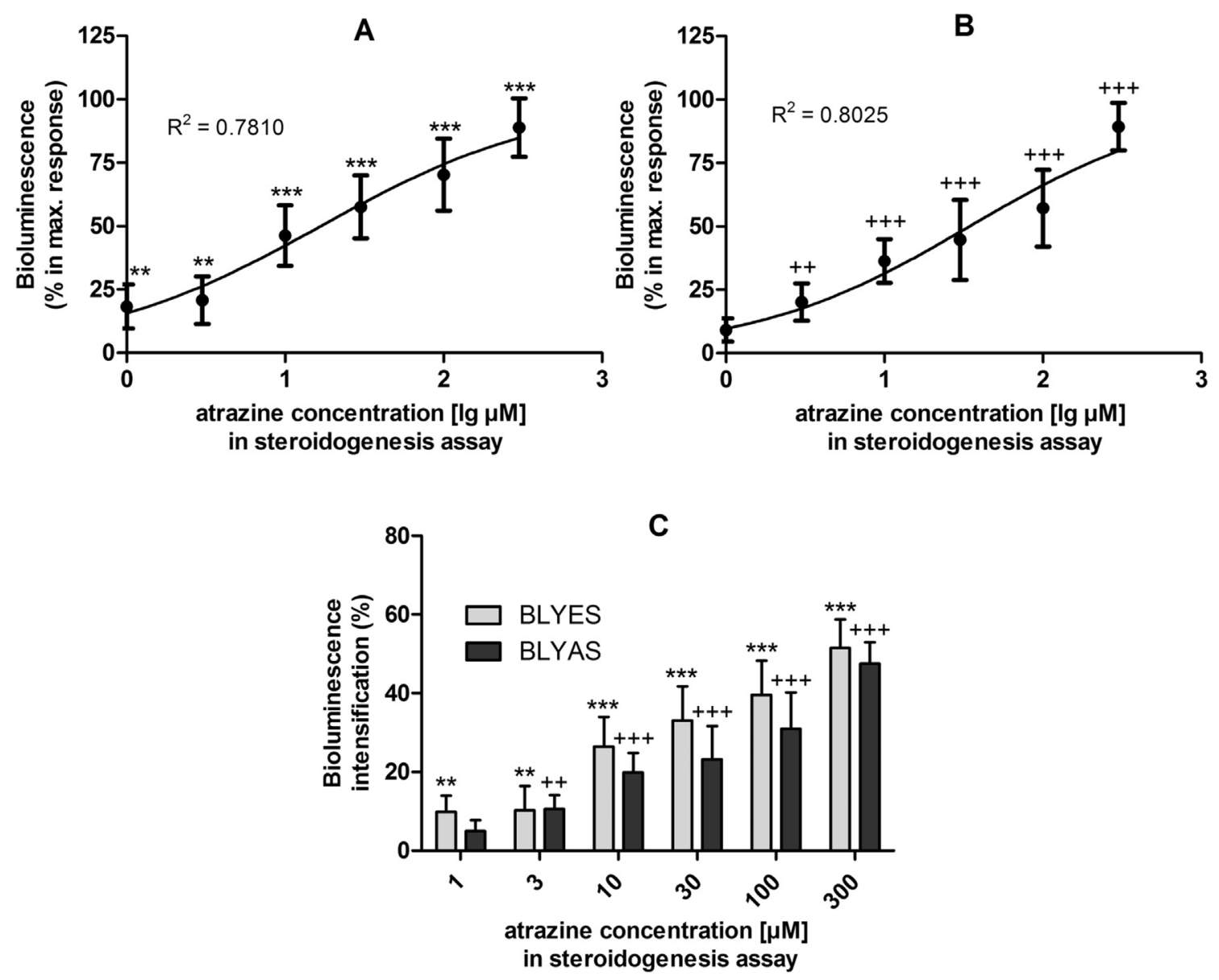

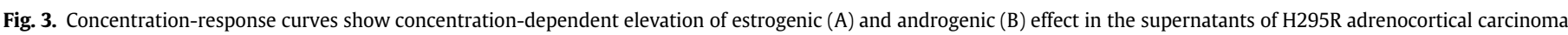

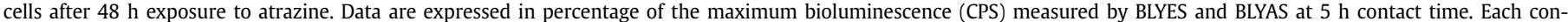

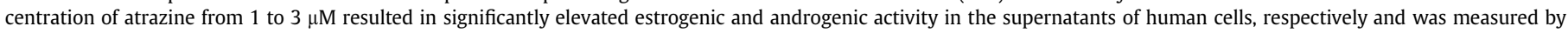

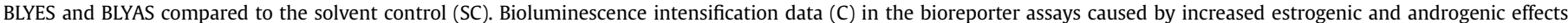

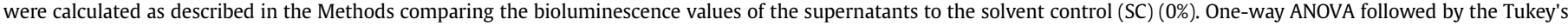

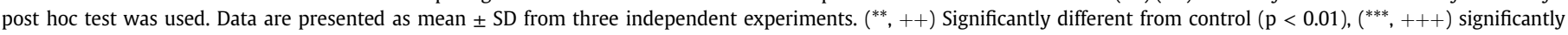
different from control $(\mathrm{p}<0.001)$.

by the BLYES and BLYAS bioreporters.

The aromatase-inductive effect of atrazine has been widely examined in several in vivo and in vitro studies. According to previous results, atrazine caused increased estrogen level in plasma, demasculinization in frogs and increased incidence of estrogendependent tumours that indicated the investigation of inductive effects of atrazine on aromatase. In previous in vivo studies, decreased testosterone level was observed in plasma in parallel with increased estrogen production (Friedmann, 2002; Trentacoste et al., 2001; Hayes et al., 2006). However, the regulation of

\section{Table 2}

Comparison of the expected $\mathrm{EC}_{50}$ ranges and the measured $\mathrm{EC}_{50}$ values regarding the positive control forskolin and prochloraz.

\begin{tabular}{lllll}
\hline Inducer/Inhibitor & \multicolumn{4}{l}{$\mathrm{EC}_{50}(\mu \mathrm{M})$ values } \\
\cline { 2 - 5 } & $\mathrm{E}^{\mathrm{a}}$ & $\mathrm{T}^{\mathrm{a}}$ & BLYES $^{\mathrm{b}}$ & BLYAS $^{\mathrm{b}}$ \\
\hline Forskolin & $0.3-3.0$ & $0.2-2.0$ & 0.609 & 0.830 \\
Prochloraz & $0.03-0.03$ & $0.01-0.1$ & 0.140 & 0.0358 \\
\hline
\end{tabular}

${ }^{\mathrm{a}}$ Expected $\mathrm{EC}_{50}$ ranges for forskolin and prochloraz using $17 \beta$-estradiol (E2) and testosterone ( $\mathrm{T}$ ) as measuring end-points (OCSPP Guideline 890.1550).

b $\mathrm{EC}_{50}$ values for forksolin and prochloraz using yeast based bioreporter tests to measure hormone activity in supernatants of H295R cells (BLYES for estrogenicity and BLYAS for androgenicity) in this study. steroidogenic genes is very difficult and the effects of various EDCs are highly complex and poorly understood.

Aside from the expected estrogenic effect, our study has shown that atrazine is able to induce the synthesis of androgen hormones in H295R human adrenocortical cells, as well.

The main subset of androgens, known as adrenal androgens, is composed of 19-carbon steroids synthesized in the zona reticularis, the innermost layer of the adrenal cortex. Beside testosterone, being the main target of androgens in steroidogenesis assays, androgens include other hormones i.e. dehydroepiandrosterone, androstendione, androstendiol, androsterone and dihydrotestosterone. Atrazine showed inhibitory effect of $5 \alpha$-reductase in earlier studies. This enzyme is most known to convert testosterone into the more potent androgen, dihydrotestosterone (BabićGojmerac et al., 1989; Kniewald et al., 1979). However, increased androgenic effect detected in BLYAS test can be attributed to neither aromatase inductor nor to $5 \alpha$-reductase inhibitory effect. Atrazine may induce other enzyme activity and/or gene expression involved in the synthesis of androgenic hormones in H295R cells causing androgenicity. The in vivo and in vitro aromatase inducer effect of atrazine is well documented in the literature, but the increased androgen production induced by the chemical, up to the best of the authors' knowledge, has been only recorded in a couple 
of experiments. Pogrmic-Majkic et al. (2010) detected elevated androgen production induced by short-term atrazine treatment in rat Leydig-cells in vitro and in vivo and it was found that atrazine has a transient stimulatory action on steroidogenesis. When studying H295R cells, Higley et al. (2010) demonstrated that in response to atrazine the cells produce more estradiol and testosterone. The result of the combined method we have developed seems to support this; in response to atrazine the androgen and estrogen synthesis in H295R human adrenocortical carcinoma cells increased, and this resulted in an increased androgenic and estrogenic effect in the bioreporter test.

The H295R cell line combined with BLYES/BLYAS bioreporter system applied in the present study has been proven useful in identifying the cumulated biological effect of atrazine in sex steroid synthesis in vitro.

One of the advantages of the semi-quantitative method, it does not require measurement of pre-specified analytical endpoints demanding various kits and methods, since the BLYES/BLYAS system is suitable for the detection of molecules being able to attach directly to the human estrogen and androgen receptors without individual measurement of the different components.

Furthermore, the combined test allows for rapid and simple detection of the complex, indirect effect of chemicals, even combination of chemicals, certain metabolites on sex steroid synthesis without the need for costly chemical and/or immunoanalytical evaluations and related preparation and extraction procedures. Additionally, the method is also applicable in cases when the effect of the test substance(s) on steroid synthesis, hence the analytical endpoints are not possible to pre-specify accurately. By using the complex effect evaluation the false negative results due to inadequate selection and use of measurement endpoints can be avoided and the method can be a useful tool to determine the most suitable further tests and assays more efficiently.

These properties of the combined method meet many of the recommendation proposed by EDSTAC (1998) considering the scope of the Tier 1 screening and testing strategy, such as that the assays should: i. be inexpensive, quick, easy to perform; ii. capture multiple endpoints. Moreover, it fulfils the need that the test should be predictive across species; hence most of the genes and enzymes involved in adrenal steroidogenesis are present and serve the identical biochemical role in several different species and classes. After further validation and standardization, the developed combined assay can be a supplementary method assessing the indirect endocrine disrupting ability of chemicals and mixtures.

\section{Conflicts of interest}

The authors declare that there are no conflicts of interest.

\section{Acknowledgements}

This study was supported by the KTIA_AIK_12-1-2013-0017, Research Centre of Excellence - 9878/2015/FEKUT project and the Hungarian Scientific Research Fund (OTKA-109622). The authors thank members of the University of Tennessee (Knoxville, Tennessee) for the BLYES/BLYAS/BLYR bioreporter constructs.

\section{References}

Andersen, H.R., Vinggaard, A.M., Rasmussen, T.H., Gjermandsen, I.M., BonefeldJørgensen, E.C., 2002. Effects of currently used pesticides in assays for estrogenicity, androgenicity, and aromatase activity in vitro. Toxicol. Appl. Pharmacol. 179, 1-12. http://dx.doi.org/10.1006/taap.2001.9347.

Babić-Gojmerac, T., Kniewald, Z., Kniewald, J., 1989. Testosterone metabolism in neuroendocrine organs in male rats under atrazine and deethylatrazine influence. J. Steroid Biochem. 33, 141-146. http://dx.doi.org/10.1016/0022-4731(89)
90369-5.

EDSTAC, 1998. Endocrine Disruptor Screening and Testing Advisory Committee Final Report. United States Environmental Protection Agency. URL: http://www. epa.gov/endocrine-disruption/endocrine-disruptor-screening-and-testingadvisory-committee-edstac-final.

Eldridge, M.L., Sanseverino, J., Layton, A.C., Easter, J.P., Schultz, T.W., Sayler, G.S. 2007. Saccharomyces cerevisiae BLYAS, a new bioluminescent bioreporter for detection of androgenic compounds. Appl. Environ. Microbiol. 73, 6012-6018. http://dx.doi.org/10.1128/AEM.00589-07.

Friedmann, A.S., 2002. Atrazine inhibition of testosterone production in rat males following peripubertal exposure. Reprod. Toxicol. 16, 275-279. http:// dx.doi.org/10.1016/S0890-6238(02)00019-9.

Gazdar, A.F, Oie, H.K. Shackleton, C.H. Chen, T.R., Triche, TJ, Myers, C.E. Chrousos, G.P., Brennan, M.F., Stein, C.A., La Rocca, R.V., 1990. Establishment and characterization of a human adrenocortical carcinoma cell line that expresses multiple pathways of steroid biosynthesis. Cancer Res. 50, 5488-5496.

Ghosh, P., Philip, L., 2006. Environmental significance of atrazine in aqueous systems and its removal by biological processes: an overview. Glob. NEST J. 8, 159-178.

Hayes, T.B., Collins, A., Lee, M., Mendoza, M., Noriega, N., Stuart, A.A., Vonk, A., 2002. Hermaphroditic, demasculinized frogs after exposure to the herbicide atrazine at low ecologically relevant doses. Proc. Natl. Acad. Sci. U. S. A. 99, 5476-5480. http://dx.doi.org/10.1073/pnas.082121499.

Hayes, T.B., Stuart, A.A., Mendoza, M., Collins, A., Noriega, N., Vonk, A., Johnston, G., Liu, R., Kpodzo, D., 2006. Characterization of atrazine-induced gonadal malformations in African clawed frogs (Xenopus laevis) and comparisons with effects of an androgen antagonist (Cyproterone Acetate) and exogenous estrogen (17 $\beta$-Estradiol): support for the demasculinization/femi. Environ. Health Perspect. 114, 134-141. http://dx.doi.org/10.1289/ehp.8067.

Hayes, T.B., Khoury, V., Narayan, A., Nazir, M., Park, A., Brown, T., Adame, L., Chan, E., Buchholz, D., Stueve, T., Gallipeau, S., 2010. Atrazine induces complete feminization and chemical castration in male African clawed frogs (Xenopus laevis). Proc. Natl. Acad. Sci. 107, 4612-4617. http://dx.doi.org/10.1073/ pnas. 0909519107.

Hayes, T.B., Anderson, L.L., Beasley, V.R., de Solla, S.R., Iguchi, T., Ingraham, H., Kestemont, P., Kniewald, J., Kniewald, Z., Langlois, V.S., Luque, E.H., McCoy, K.A., Muñoz-de-Toro, M., Oka, T., Oliveira, C.A., Orton, F., Ruby, S., Suzawa, M., TaveraMendoza, L.E., Trudeau, V.L., Victor-Costa, A.B., Willingham, E., 2011. Demasculinization and feminization of male gonads by atrazine: consistent effects across vertebrate classes. J. Steroid Biochem. Mol. Biol. 127, 64-73. http:// dx.doi.org/10.1016/j.jsbmb.2011.03.015.

Hecker, M., Newsted, J.L., Murphy, M.B., Higley, E.B., Jones, P.D., Wu, R., Giesy, J.P., 2006. Human adrenocarcinoma (H295R) cells for rapid in vitro determination of effects on steroidogenesis: Hormone production. Toxicol. Appl. Pharmacol. 217, 114-124. http://dx.doi.org/10.1016/j.taap.2006.07.007.

Hecker, M., Giesy, J.P., 2008. Novel trends in endocrine disruptor testing: the H295R steroidogenesis assay for identification of inducers and inhibitors of hormone production. Anal. Bioanal. Chem. 390, 287-291. http://dx.doi.org/10.1007/ s00216-007-1657-5.

Higley, E.B., Newsted, J.L., Zhang, X., Giesy, J.P., Hecker, M., 2010. Assessment of chemical effects on aromatase activity using the H295R cell line. Environ. Sci. Pollut. Res. Int. 17, 1137-1148. http://dx.doi.org/10.1007/s11356-009-0285-3.

Kniewald, J., Mildner, P., Kniewald, Z., 1979. Effects of s-triazine herbicides on hormone-receptor complex formation, 5 alpha-reductase and 3 alphahydroxysteroid dehydrogenase activity at the anterior pituitary level. J. Steroid Biochem. 11 (1C), 833-838.

Kniewald, J., Jakominić, M., Tomljenović, A., Simić, B., Romać, P., Vranesić, D., Kniewald, Z., 2000. Disorders of male rat reproductive tract under the influence of atrazine. J. Appl. Toxicol. 20 (1), 61-68. http://dx.doi.org/10.1002/(SICI)10991263(200001/02)20, 1<61::AID-JAT628>3.0.CO;2-3.

Kojima, H., Katsura, E., Takeuchi, S., Niiyama, K., Kobayashi, K., 2003. Screening for estrogen and androgen receptor activities in 200 pesticides by in vitro reporter gene assays using Chinese hamster ovary cells. Environ. Health Perspect. 112, 524-531. http://dx.doi.org/10.1289/ehp.6649.

Krifaton, C., Kriszt, B., Risa, A., Szoboszlay, S., Cserháti, M., Harkai, P., Eldridge, M., Wang, J., Kukolya, J., 2013. Application of a yeast estrogen reporter system for screening zearalenone degrading microbes. J. Hazard. Mater. 244, 429-435. http://dx.doi.org/10.1016/j.jhazmat.2012.11.063.

Oka, T., Tooi, O., Mitsui, N., Miyahara, M., Ohnishi, Y., Takase, M., Kashiwagi, A., Shinkai, T., Santo, N., Iguchi, T., 2008. Effect of atrazine on metamorphosis and sexual differentiation in Xenopus laevis. Aquat. Toxicol. 87, 215-226. http:// dx.doi.org/10.1016/j.aquatox.2008.02.009.

Paranjape, K., Gowariker, V., Krisnamurthy, V.N., Gowariker, S., 2014. The Pesticide Encyclopedia, first ed. CABI, Wallingford.

Pintér, A., Török, G., Börzsönyi, M., Surján, A., Csík, M., Kelecsényi, Z., Kocsis, Z., 1990. Long-term carcinogenicity bioassay of the herbicide atrazine in F344 rats. Neoplasma 37, 533-544. http://dx.doi.org/10.1016/0165-1161(90)90116-6.

Pogrmic-Majkic, K., Fa, S., Dakic, V., Kaisarevic, S., Kovacevic, R., 2010. Upregulation of peripubertal rat leydig cell steroidogenesis following $24 \mathrm{~h}$ in vitro and in vivo exposure to atrazine. Toxicol. Sci. 118, 52-60. http://dx.doi.org/10.1093/toxsci/ kfq227.

Rainey, W.E., Bird, I.M., Sawetawan, C., Hanley, N.A., McCarthy, J.L., McGee, E.A., Wester, R., Mason, J.I., 1993. Regulation of human adrenal carcinoma cell (NCIH295) production of C19 steroids. J. Clin. Endocrinol. Metab. 77 (3), 731-737. http://dx.doi.org/10.1210/jcem.77.3.8396576. 
Rainey, W.E., Bird, I.M., Mason, J.I., 1994. The NCI-H295 cell line: a pluripotent model for human adrenocortical studies. Mol. Cell. Endocrinol. 100, 45-50. http:// dx.doi.org/10.1016/0303-7207(94)90277-1.

Roberge, M., Hakk, H., Larsen, G., 2004. Atrazine is a competitive inhibitor of phosphodiesterase but does not affect the estrogen receptor. Toxicol. Lett. 154 61-68. http://dx.doi.org/10.1016/j.toxlet.2004.07.005.

Routledge, E.J., Sumpter, J.P., 1996. Estrogenic activity of surfactants and some of their degradation products assessed using a recombinant yeast screen. Environ. Toxicol. Chem. 15, 241-248. http://dx.doi.org/10.1002/etc.5620150303.

Sanderson, J.T., Seinen, W., Giesy, J.P., van den Berg, M., 2000. 2-Chloro-s-triazine herbicides induce aromatase (CYP19) activity in H295R human adrenocortical carcinoma cells: a novel mechanism for estrogenicity? Toxicol. Sci. 54,121-127.

Sanderson, J.T., Boerma, J., Lansbergen, G.W.A., Van Den Berg, M., 2002. Induction and inhibition of aromatase (CYP19) activity by various classes of pesticides in H295R human adrenocortical carcinoma cells. Toxicol. Appl. Pharmacol. 182, 44-54. http://dx.doi.org/10.1006/taap.2002.9420.

Sanseverino, J., Gupta, R.K., Layton, A.C., Patterson, S.S., Ripp, S., Saidak, L. Simpson, M.L., Schultz, T.W., Sayler, G.S., 2005. Use of Saccharomyces cerevisiae BLYES expressing bacterial bioluminescence for rapid, sensitive detection of estrogenic compounds. Appl. Environ. Microbiol. 71, 4455-4460. http:/ dx.doi.org/10.1128/AEM.71.8.4455-4460.2005.

Sanseverino, J., Eldridge, M.L., Layton, A.C., Easter, J.P., Yarbrough, J., Schultz, T.W., Sayler, G.S., 2009. Screening of potentially hormonally active chemicals using bioluminescent yeast bioreporters. Toxicol. Sci. 107, 122-134. http://dx.doi.org/ $10.1093 /$ toxsci/kfn229.

Sass, J.B., Colangelo, A., 2006. European Union bans atrazine, while the United States negotiates continued use. Int. J. Occup. Environ. Health 12, 260-267. http:// dx.doi.org/10.1179/oeh.2006.12.3.260.

Seamon, K.B., Padgett, W., Daly, J.W., 1981. Forskolin: unique diterpene activator of adenylate cylase in membranes and in intact cells. PNAS 78, 3363-3367.

Suzawa, M., Ingraham, H.A., 2008. The herbicide atrazine activates endocrine gene networks via non-steroidal NR5A nuclear receptors in fish and mammalian cells. PLoS One 3, 1-18. http://dx.doi.org/10.1371/journal.pone.0002117.

Trentacoste, S.V., Friedmann, A.S., Youker, R.T., Breckenridge, C.B., Zirkin, B.R., 2001. Atrazine effects on testosterone levels and androgen-dependent reproductive organs in peripubertal male rats. J. Androl. 22, 142-148. http://dx.doi.org/ 10.1002/j.1939-4640.2001.tb02164.x.

U.S. Environmental Protection Agency, 2011. Steroidogenesis (Human Cell Line H295R) OCSPP Guideline 890.1550. Standard Evaluation Procedure (SEP) Endocrine Disruptor Screening Program.

Vinggaard, A.M., Nellemann, C., Dalgaard, M., Jørgensen, E.B., Andersen, H.R., 2002 Antiandrogenic effects in vitro and in vivo of the fungicide prochloraz. Toxicol Sci. 69, 344-353. http://dx.doi.org/10.1093/toxsci/69.2.344.

Vinggaard, A.M., Hass, U., Dalgaard, M., Andersen, H.R., Bonefeld-Jorgensen, E. Christiansen, S., Laier, P., Poulsen, M.E., 2006. Prochloraz: an imidazole fungicide with multiple mechanisms of action. Int. J. Android 129 (1), 186-192. http://dx.doi.org/10.1111/j.1365-2605.2005.00604.x.

WHO-IARC Monographs on the Evaluation of Carcinogenic Risks to Humans, 1999 Some Chemicals that Cause Tumors of the Kidney or Urinary Bladder in Rodents and Some Other Substances, 73. International Agency for Research on Cancer; Lyon. 